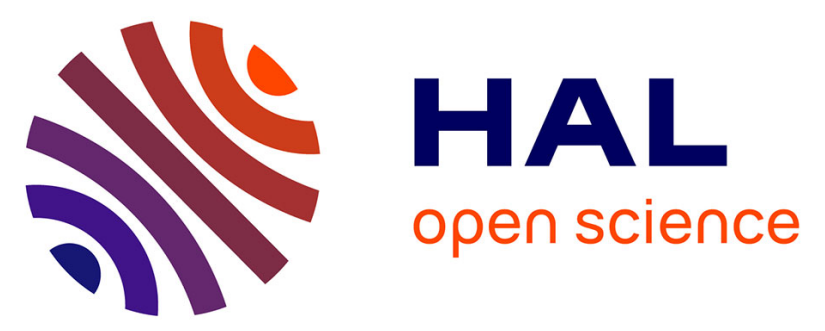

\title{
Study of the burning of Pteridium aquilinum L. and risk for the personnel involved: Thermal properties and chemical risk
}

Toussaint Barboni, Lara Leonelli, Paul-Antoine Santoni, Virginie

Tihay-Felicelli

\section{To cite this version:}

Toussaint Barboni, Lara Leonelli, Paul-Antoine Santoni, Virginie Tihay-Felicelli. Study of the burning of Pteridium aquilinum L. and risk for the personnel involved: Thermal properties and chemical risk.

Fire Safety Journal, 2019, 110, pp.102904 -. 10.1016/j.firesaf.2019.102904 hal-03488776

\section{HAL Id: hal-03488776 \\ https://hal.science/hal-03488776}

Submitted on 21 Dec 2021

HAL is a multi-disciplinary open access archive for the deposit and dissemination of scientific research documents, whether they are published or not. The documents may come from teaching and research institutions in France or abroad, or from public or private research centers.
L'archive ouverte pluridisciplinaire HAL, est destinée au dépôt et à la diffusion de documents scientifiques de niveau recherche, publiés ou non, émanant des établissements d'enseignement et de recherche français ou étrangers, des laboratoires publics ou privés.

\section{(ㅇ)(1) $\$$}

Distributed under a Creative Commons Attribution - NonCommerciall 4.0 International 


\title{
Study of the burning of Pteridium aquilinum $L$. and risk for the personnel involved: thermal properties and chemical risk
}

\author{
T. Barboni, L. Leonelli, P.A. Santoni, V. Tihay-Felicelli
}

University of Corsica - CNRS UMR 6134 SPE, Campus Grimaldi, BP 52, 20250 Corte, France

\section{Corresponding author:}

Toussaint Barboni

University of Corsica - CNRS UMR 6134 SPE, Campus Grimaldi, BP 52, 20250 Corte, France,

Phone: +33 495450 046, Fax: +33 495450 162, E-mail address: barboni@univ-corse.fr

\begin{abstract}
:
We studied the burning of fern at the request of firefighters who felt strong irritation during its combustion. Smoke from forest fires is hazardous to health and can result acute or chronic toxicity. Also, smoke is opaque resulting in decreased vision. In this study, leaves and stems of ferns were burned according to the vegetative state ie dead and alive with a cone calorimeter. Time to ignition ( $\left.t_{i g}\right)$ and Heat Release Rate (HRR) were measured. The smoke emitted was analysed by non-dispersive infrared (NDIR) spectroscopy, He-Ne laser, Fourier-transform infrared (FTIR) spectroscopy, and automated-thermal-desorption-gas-chromatography/massspectrometry (ATD-GC/MS). Analysis of the smoke reveals that the major compounds are $\mathrm{CO}_{2}$, $\mathrm{H}_{2} \mathrm{O}$, CO, aerosols, $\mathrm{NO}$, and $\mathrm{SO}_{2}$. Other gases in smaller proportions were observed, as well as non-methane organic compounds (NMOCs). These high levels of $\mathrm{SO}_{2}$ and $\mathrm{HCl}$ may be responsible of severe irritation for firefighters. Even at low concentrations, sulfur dioxide is an irritating gas for the nose and upper airways. Exposure to hydrochloric acid causes irritating effects on the skin and eyes. $\mathrm{SO}_{2}$ and $\mathrm{HCl}$ are corrosive to the eyes and skin. Finally, 97.8 and $96.1 \%$ of the carbon present in the fuel was identified in the emitted smoke for the dead and alive ferns respectively.
\end{abstract}

Keywords: smoke emission, heat release rate, emission factor, gases, VOC, aerosols

\section{Highlights}

Heat Release Rate and Smoke Production Rate from burning dead and alive ferns; Emission factor of gases, volatile organic compounds and aerosols emitted during the fern combustion; High levels of $\mathrm{SO}_{2}$ and $\mathrm{HCl}$ may be responsible of the severe irritation for firefighters. 


\section{Abbreviations}

a

Aerosol

$b \quad$ Burned

$\mathrm{CM}_{\mathrm{i}} \quad$ Carbon mass in a gaseous compound $i$ by dry mass of vegetation burned ( $\left(\mathrm{g}_{\mathrm{C}} \cdot \mathrm{kg}^{-1}\right)$

dry Dry

EC Elemental Carbon $(\mu \mathrm{g})$

EF Emission factor $\left(\mathrm{g} \cdot \mathrm{kg}^{-1}\right)$

FID Flame Ionization Detector

FTIR Fourier Transform Infrared Spectrometer

HHV Higher Heating Value $\left(\mathrm{kJ}^{\mathrm{kg}} \mathrm{kg}^{-1}\right)$

$k \quad$ Light extinction coefficient $\left(\mathrm{m}^{-1}\right)$

LHV Lower Heating Value $\left(\mathrm{kJ} \mathrm{kg}^{-1}\right)$

$m \quad$ Mass $(\mathrm{kg})$

$m_{a} \quad$ Aerosols mass (kg)

$n_{c} \quad$ Number of carbon atoms (-)

NMOC Non-methane organic compounds

NDIR Non-dispersive infrared gas analyzer

OC Organic carbon $(\mu \mathrm{g})$

$\mathrm{O}_{2} \quad$ Oxygen

SPR Smoke Production Rate $\left(\mathrm{m}^{2} \cdot \mathrm{s}^{-1}\right)$

SEA Smoke Extinction Area $\left(\mathrm{m}^{2} \cdot \mathrm{kg}^{-1}\right)$

$t \quad$ Time (s)

$T \quad$ Temperature (K)

TSP Total Smoke Production $\left(\mathrm{m}^{2}\right)$

$\dot{V} \quad$ Standard flow rate in the exhaust duct at $298 \mathrm{~K}\left(\mathrm{~m}^{3} \cdot \mathrm{s}^{-1}\right)$

VOC Volatile organic compound

w $\quad$ Molecular weight $\left(\mathrm{kg} \cdot \mathrm{mol}^{-1}\right)$

$\sigma_{a} \quad$ Specific extinction area $\left(\mathrm{m}^{2} \cdot \mathrm{kg}^{-1}\right)$ 


\section{Introduction}

The forest fires are a major problem. During these fires, smoke is emitted into the atmosphere. This raises to an important public health issue, entails major risks for the health of the personnel involved and he populations and has negative impacts on air quality. Smoke contains a complex mixture of gases, volatile organic (VOC) and semi-volatiles (SCOV) compounds and aerosols [1,2]. These primary pollutants undergo physicochemical transformations in the atmosphere to give rise to secondary pollutants. An aerosol is a suspension of solid or liquid particles in the air. For health purposes, aerosols or particulate matters (PM) are typically defined by their size, with the smaller particles having more health impact. Smoke is mainly constituted of carbon dioxide $\mathrm{CO}_{2}$, water $\mathrm{H}_{2} \mathrm{O}$, carbon monoxide $\mathrm{CO}$, aerosols $\left(\mathrm{PM}_{2.5}\right)$, nitrogen oxides $\mathrm{NOx}$, methane $\mathrm{CH}_{4}$, ammonia $\mathrm{NH}_{3}$ and sulfur dioxide $\mathrm{SO}_{2}$ [39]. The amount of $\mathrm{CO}_{2}$ emitted from fires in the US is equivalent to $4-6 \%$ of anthropogenic emissions at the continental scale and, at the state-level, fire emissions of $\mathrm{CO}_{2}$ can, in some cases, exceed annual emissions of $\mathrm{CO}_{2}$ from fossil fuel usage [10]. Few amounts of VOCs and SCOVs are emitted [11-13] but these compounds are considered to be very toxic for Human and the environment. Benzene is the major non-methane organic compounds (NMOCs) [11, 13] emitted.

For the objective of forest fire prevention, managers use several techniques, such as mechanical brushing and prescribed burning. Prescribed burnings use fire in a specific area to achieve predetermined forest management or other territorial developments. It consists of suppressing by fire the grass, brush, litter, slash, branches, dead wood or forest-dwelling species which may promote fire spread after their withering. Firefighters intervening on these prescribed burnings or during forest fires are exposed to toxic smoke. During the operations, they provide a considerable level of effort and their interventions can last several hours in a row and extend over a long period. Some studies report respiratory and neurological disorders that may affect firefighters [14-17]. Chemical exposure can occur via inhalation, ingestion but also absorption through the skin. Gaseous effluents may also condense on protective equipment and exposed skin, leaving an oily residue or film. These chemicals can pose a significant threat to firefighters' health directly (via the skin and eyes, or by inhalation) or following dermal absorption [18]. Progressive loss of respiratory function has been observed over the course of the seasons, and behavioral disturbances have been identified that can create dangerous situations during the transmission of orders. Firefighters underestimate the risks associated with 
forest fires smoke and particularly during prescribed. Currently, there is no protection of the respiratory airways adapted to the specificity of firefighting operations in wildfires. Protection systems are unsuitable for firefighting on wildfires or prescribed burnings, only the hood serves as protection of the respiratory tract. Respiratory systems (Personal Protective Equipment PPE) are too heavy to handle for instance in steep slopes. They are bulky in a harsh environment where vegetation branches can hinder progression and/or unbearable in hot weather.

The Pteridium aquilinum was studied at the request of firefighters who felt severe irritation during its combustion. During prescribed burnings, they have experienced exacerbated irritation in the presence of ferns. P. aquilinum, from the family Dennstaedtiaceae, also supports more humid growing conditions, because it is sometimes found in the natural environment on the edges of swamps. However, its plantation in dry forest is preferable. The fern-eagle has an almost global distribution in dry forests, it is the main fern in most situations in partial shade on dry ground. It is present in Europe because it is adapted to European climates. Laboratory experiments were conducted with a cone calorimeter coupled with analytical chains for the burning of stems and leaves of alive and dead ferns. Thermal and chemical parameters were determined in order to measure the ignitability, combustibility and emissions of chemical species for the burning of fern according to its stage of development. The first section presents the material and methods as well as the vegetation fuel. The results are provided in the second section where we discuss the burning and smoke composition characteristics of fern by comparison to those of Cistus monspeliensis an abundant vegetation of the Mediterranean basin.

\section{Experimental}

\subsection{Fuel description}

Pteridium aquilinum $L$. belongs to the family of hypolepidaceas (Fig. 1). It is a perennial geophyte whose size can vary between 0.4 and $2.5 \mathrm{~m}$ in height. It has a deep rhizomatous strain, black in color, fibrous and branched. Its aerial part consists of a long, thick petiole up to $1.5 \mathrm{~m}$ long, and large fronds, 30 to $90 \mathrm{~cm}$ wide, triangular in shape, and divided [19]. All aerial parts of the plant are toxic because of their aquilide A content and cyanide derivatives [20]. 


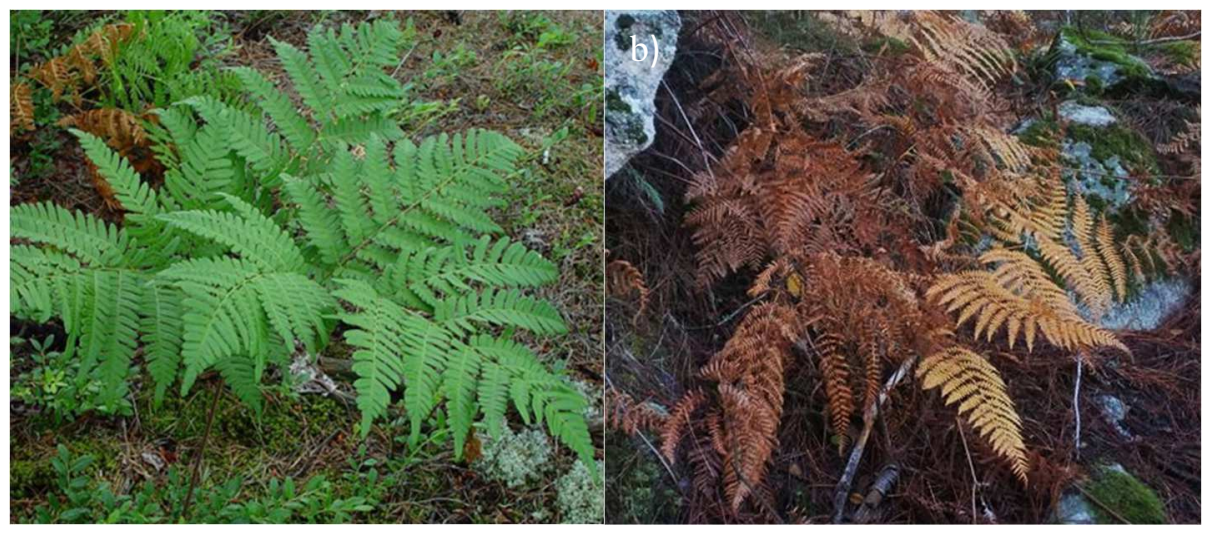

Figure 1. Picture of fern at different physiological stages a) alive, b) dead.

The fern used for this study was collected on the territory of the municipality of Corte, in the Restonica Valley $\left(42^{\circ} 16^{\prime} 33^{\prime \prime} \mathrm{N} / 9^{\circ} 06^{\prime 2} 29^{\prime \prime E}\right)$ at $600 \mathrm{~m}$ altitude, during spring and fall, to study the plant according to its stages of development. After harvesting, the plant was oven dried at $60{ }^{\circ} \mathrm{C}$ for 48 hours. The leaves had a characteristic thickness of $0.5 \mathrm{~mm}$. A mass of $6 \mathrm{~g}$ of leaves were placed in a basket and arranged with an apparent surface of around $100 \mathrm{~cm}^{2}$. The stems were cut into sticks of $10 \mathrm{~cm}$ long with a characteristic thickness of $5 \pm 1 \mathrm{~mm}$. 16 fern stems were placed in the sample holder to fill it, which corresponds to an apparent fuel surface of $100 \mathrm{~cm}^{2}$ (Fig. 2). The sampler holder is a basket specifically designed for the cone calorimeter. Its dimensions are $10 \mathrm{~cm}$ of side and $2 \mathrm{~cm}$ height (Fig. 2). It is made of stainless steel and has uniform holes creating an open boundary for air to flow into the holder and through the vegetation particles. The stems and leaves were placed under the cone calorimeter inside the sample holder in a parallel arrangement (Fig. 2). The sample holder was filled, avoiding the superposition of leaves (Fig. 2). To ensure that the surfaces of the fuels underwent the same heat flux from the cone heater.
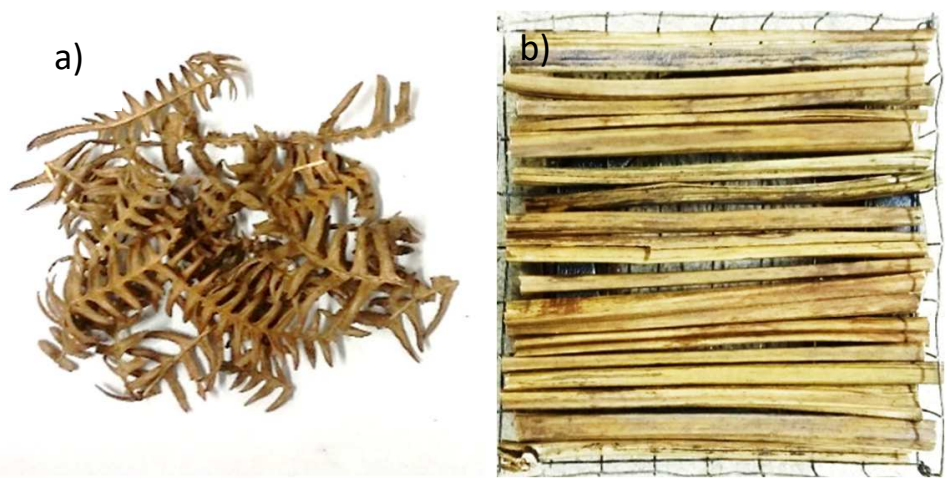

Figure 2. Picture of samples of ferns dry: a) leaves and b) stems in the holder 
2.2. Ultimate analysis and higher and lower heating values of Pteridium aquilinum $L$.

Plants are organic compounds: carbon, hydrogen and oxygen, in fairly constant proportions, given the great diversity of the latter [21]. The ultimate analyzes of the plants were carried out by SOCOR $®$. The results are presented in Table 1 . The value are mass percentages expressed on a dry matter basis.

Table 1. Elementary analysis of Pteridium aquilinum L. plants.

\begin{tabular}{ccccccc}
\hline Plant species & $\begin{array}{c}\text { Carbon } \\
(\%)\end{array}$ & $\begin{array}{c}\text { Hydrogen } \\
(\%)\end{array}$ & $\begin{array}{c}\text { Oxygen } \\
(\%)\end{array}$ & $\begin{array}{c}\text { Nitrogen } \\
(\%)\end{array}$ & $\begin{array}{c}\text { Sulfur } \\
\left(\mathrm{mg}^{\left.-\mathrm{kg}^{-1}\right)}\right)\end{array}$ & $\begin{array}{c}\text { Chlorine } \\
\left(\mathrm{mg}^{\left.-\mathrm{kg}^{-1}\right)}\right.\end{array}$ \\
\hline $\begin{array}{c}\text { Leaves and steam } \\
\text { dead }\end{array}$ & 50.3 & 5.49 & 38.5 & 0.58 & 567 & 2451 \\
\hline $\begin{array}{c}\text { Leaves and steam } \\
\text { alive }\end{array}$ & 47.7 & 5.42 & 35.7 & 3.32 & 2181 & 4262 \\
\hline
\end{tabular}

We note differences in the constituent elements of the fern depending on its stage of development. Dead fern has more carbon and oxygen while alive fern contains a lot of nitrogen. High proportions of sulfur and chlorine are present in the fern. These proportions are more important in the alive fern than in the dead one. This difference should lead to a higher proportion of nitrogen, sulfur and chlorine compounds in the smokes from burning fern. The differences of element $\mathrm{S}$ and $\mathrm{Cl}$ according to the vegetative cycle can be explained by the cycle of these contributions over time. There is a cycle of absorption of elements and transformation depending on the vegetative cycle of the plant. Plants absorb sulfur from their roots by sulfate (SO42-). $\mathrm{S}$ is essential for the synthesis of proteins and especially for the formation of chlorophyll during vegetal cycle. The roots easily absorb chlorine ( $\mathrm{Cl}-)$ and this is very mobile in the plant. Chlorine is necessary for photosynthesis. HHV and LHV of fuels were provided by SOCOR $®$ (Table 2). Whatever the physiological stages of fern, the LHV are around 18500 $\mathrm{kJ} / \mathrm{kg}$ and the $\mathrm{HHV}$ around $19600 \mathrm{~kJ} / \mathrm{kg}$. These values are consistent with literature which gives

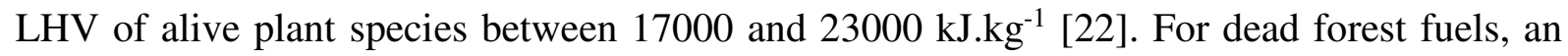
average value of $18700 \mathrm{~kJ}^{\mathrm{kg}} \mathrm{kg}^{-1}$ is generally used whatever the fuel because the variation from one species to another is not significant [23]. 
Table 2. Higher and lower heating values from Fern

\begin{tabular}{ccc}
\hline & HHV $\left(\mathrm{kJ} \cdot \mathrm{kg}^{-1}\right)$ & LHV $\left(\mathrm{kJ}^{-1} \mathrm{~kg}^{-1}\right)$ \\
\hline Leaves and steam dead & 19674 & 18543 \\
\hline Leaves and steam alive & 19630 & 18450 \\
\hline
\end{tabular}

\subsection{Experimental design}

Fuel samples were burned using a cone calorimeter (Fig. 3) coupled to an Antaris IGS FTIR Spectrometer (ThermoFisher Scientific). The cone calorimeter (ISO 5660) was composed of a cone heater, a shutter, a load cell, and an exhaust system with gas analysers. Samples were exposed to a radiant heat flux of $50 \mathrm{~kW} \cdot \mathrm{m}^{-2}$; this value was chosen because it corresponds to the levels of heat flux measured in shrubland fires ahead of a fire front [24].

Further cone-calorimeter details are provided in a previous publication [8]. Smoke was

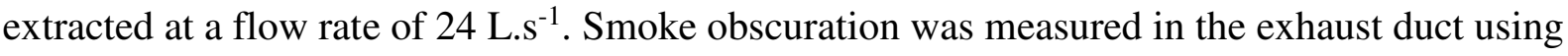
a He-Ne laser $(0.5 \mathrm{~mW}$ nominal power $)$ that emits red light $(\lambda=632.8 \mathrm{~nm})$. The optical path length of the exhaust duct was $11.4 \mathrm{~cm}$. Carbon monoxide and carbon dioxide were continuously quantified by non-dispersive infrared (NDIR) spectroscopy, and all gases were quantified by FTIR spectroscopy. The calibration gas contained $2500 \mathrm{ppm} \mathrm{CO}$ and $8 \% \mathrm{CO}_{2}$. VOCs and SVOCs were sampled during combustion with a sample pump (2 L.min ${ }^{-1}$ ) using Tenax tubes (Supelco®, Saint-Quentin Fallavier, France) according to the combustion stage. Tenax TA sorbent multi-bed glass tubes $(11.5 \mathrm{~cm} \times 6 \mathrm{~mm}$ (o.d.) $\times 4 \mathrm{~mm}$ (i.d.)) were used to capture organic compounds of low and medium volatility. Analyses were conducted following thermal desorption with an automated thermal desorption - gas chromatography / mass spectrometry (ATD-GC/MS) system. It should be noted that sorbent tubes have previously been used in other studies for sampling VOCs and SVOCs [5, 25] prior to GC/MS analysis. Aerosols were sampled in the cone-calorimeter duct with a sample pump. They were collected on glass fibre filters and weighed using a precision balance (Balco Mettler ${ }^{\circledR}-\mathrm{AE} 200$, precision: $10^{-5}$ g). The total mass of the aerosols produced was determined from the ratio of the smoke flux from the calorimeter cone to the flow rate of the sampling pump. 
The smoke obscuration was measured in the exhaust ducts with a He-Ne laser. Östman and Tsantaridis [26] have shown that He-Ne laser and white light system give equal results. In our work, the measured parameters were the smoke production rate (SPR), the total smoke production (TSP), the mass of aerosols and the smoke extinction area (SEA). The SPR was calculated according to the basic smoke equation:

$$
S P R=k \dot{V}
$$

where $k$ is the light extinction coefficient given by the Bouguer's law and $\dot{V}$ is the standard flow rate in the exhaust duct. Then the TSP was obtained by:

$$
T S P=\int_{0}^{t_{f i}} S P R d t
$$

The SEA corresponds to the ratio of the smoke production rate to the mass loss rate (MLR):

$$
S E A=\frac{S P R}{M L R}
$$

The mass of aerosols $\left(m_{a}\right)$ released during the burning was calculated using the following equation:

$$
m_{a}=\int_{0}^{T} \frac{k}{\sigma_{a}} \dot{V} d t
$$

where $\sigma_{a}$ is the specific extinction area. The values used for this study corresponds to those reported by Leonelli et al., [27]: $\sigma_{a}=8290 \mathrm{~m}^{2} \cdot \mathrm{kg}^{-1}$ during the flaming stage and $\sigma_{a}=$ $3290 \mathrm{~m}^{2} \cdot \mathrm{kg}^{-1}$ during smouldering and pre-ignition stages.

The total carbon mass balance was used to check the quantities of analysed gases. Indeed, when quantifying emitted compounds, one must check that the analysed carbon content does not exceed that found in the plant by ultimate analysis. Hence, the mass of carbon for each analysed compound of smoke $i$ per kilogram of dry plant burned $\left(C M_{i}\right)$ was calculated according to the equation:

$$
C M_{i}=E F_{i} \times \frac{W_{c}}{W_{i}} \times n_{c i}
$$

where $E F_{i}$ is the emission factor of compound $i$ (mass of compound $i$ emitted per kilogram of dry plant burned), $W_{C}$ and $W_{i}$ are the molecular weights of carbon and compound $i$, respectively and $n_{C i}$ is the number of carbon atoms present in compound $i$. The same equation was used for the sulphur and chlorine mass balance. 


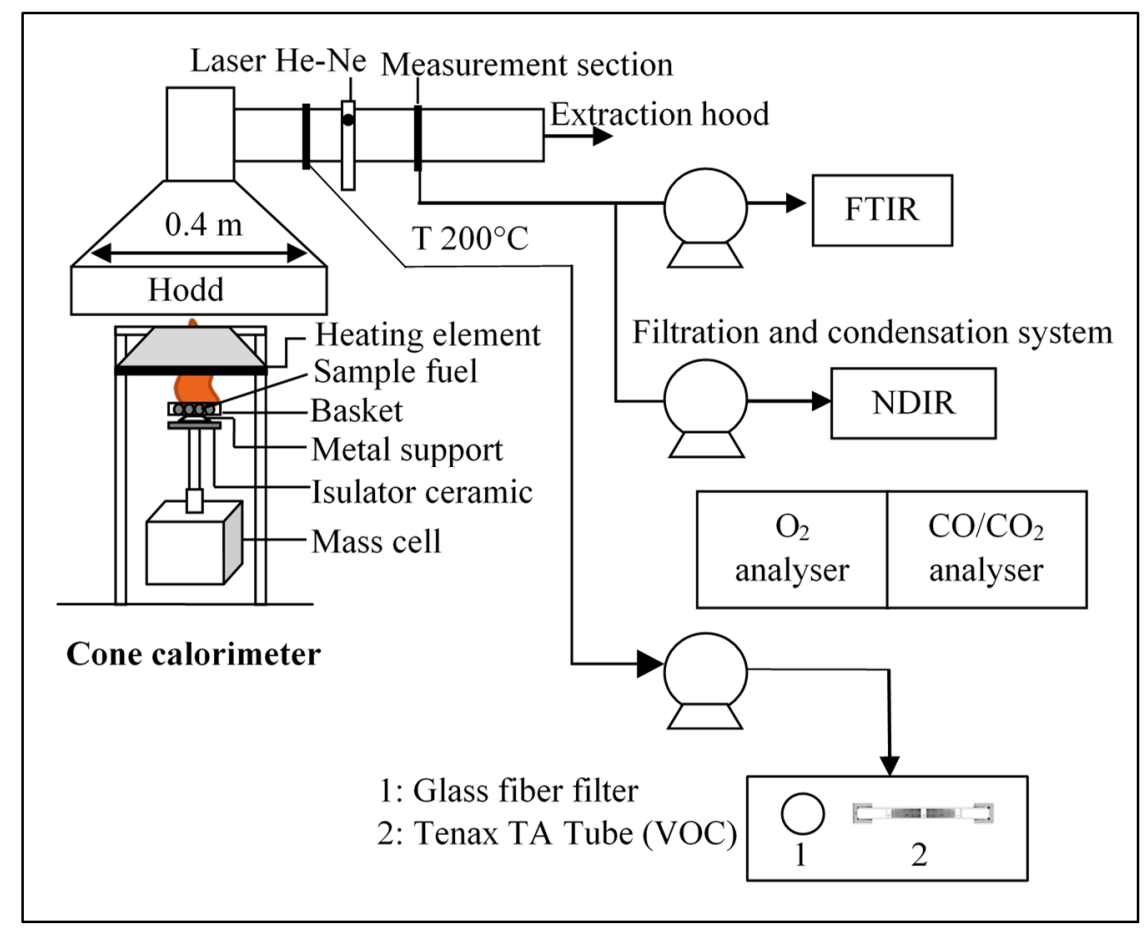

Figure 3. Experimental device: schematic of the cone calorimeter and analysers for analysing the sampled gas, VOCs, and aerosols.

\subsection{Chemical analysis \\ FTIR spectroscopy}

Smoke was analysed by identifying and quantifying the effluent gaseous compounds and by quantifying the opacity caused by the aerosols. The molar fractions of $\mathrm{CO}_{2}, \mathrm{CO}, \mathrm{CH}_{4}, \mathrm{NO}, \mathrm{NO}_{2}$, $\mathrm{NH}_{3}, \mathrm{C}_{2} \mathrm{H}_{6}, \mathrm{C}_{2} \mathrm{H}_{4}, \mathrm{C}_{2} \mathrm{H}_{2}, \mathrm{C}_{3} \mathrm{H}_{8}, \mathrm{C}_{3} \mathrm{H}_{6}, \mathrm{C}_{4} \mathrm{H}_{6}, \mathrm{C}_{6} \mathrm{H}_{6}, \mathrm{HCHO}, \mathrm{CH}_{3} \mathrm{CHO}, \mathrm{SO}_{2}$, and $\mathrm{H}_{2} \mathrm{O}$ were determined by FTIR spectroscopy with the Antaris IGS FTIR. This spectrometer is equipped with a MCT-A detector and a gas cell measurement of volume of $0.2 \mathrm{~L}$ with an optical path length of $2 \mathrm{~m}$. IR spectra were recorded in the $4500-550 \mathrm{~cm}^{-1}$ spectral range with a resolution of $0.5 \mathrm{~cm}^{-1}$. A filter that removed aerosols was placed before the gas cell, and the sampling line was heated to $180^{\circ} \mathrm{C}$ to avoid condensation. The flow rate inside the spectrometer was set to 3.5 L. $\mathrm{min}^{-1}$. The molar fraction of $\mathrm{O}_{2}$ was measured with a paramagnetic analyser, and the $\mathrm{CO}$ and $\mathrm{CO}_{2}$ molar fractions were determined by NDIR spectroscopy. The flow rate of the sampling pump was set to $3.5 \mathrm{~L} \cdot \mathrm{min}^{-1}$, and the gas-sampled water was removed using a cold trap. To obtain the actual molar fraction of $\mathrm{O}_{2}$, a correction that takes into account the amount of water present in the smoke was applied to the values determined by the paramagnetic analyser. Finally, the amount of $\mathrm{N}_{2}$ was deduced from the molar fractions of the other gases. 
The generation of combustion products was quantified in terms of emission factors, $E F_{i}$ $\left(\mathrm{g} . \mathrm{kg}^{-1}\right)$, defined as the mass of chemical species $i$ produced per dry mass of fuel burned, $m_{b, d r y}$ (Andreae and Merlet, 2001)

$E F_{i}=\frac{m_{i}}{m_{b, d r y}}$

where $m_{i}(\mathrm{~kg})$ is the mass of compound $i$ released by the burning and $m_{b, d r y}(\mathrm{~kg})$ is the dry mass burned during the experiments.

Although the samples were dried in an oven, they partly rehydrated during the preparation of the test (set up vegetation in the basket) up to $3 \%$ of FMC. The residual mass was composed of ashes since all the samples burned totally.

To evaluate the combustion completeness, the modified combustion efficiency (MCE) is introduced, as follows:

$M C E=\frac{\left[\mathrm{CO}_{2}\right]}{\left[\mathrm{CO}_{2}\right]+[\mathrm{CO}]}$

where $\left[\mathrm{CO}_{2}\right]$ and $[\mathrm{CO}]$ are the molar concentrations of emitted $\mathrm{CO}_{2}$ and $\mathrm{CO}$ in the smoke. Fireintegrated excess molar mixing ratios of $\mathrm{CO}_{2}$ and $\mathrm{CO}$ were used to calculate mean modified combustion efficiencies.

Automated thermal desorption - gas chromatography / mass spectrometry (ATD-GC/MS) system

A sampling line and a filter (to trap particulates) were used in conjunction with a pump that drew smoke into a Tenax tube (Supelco ${ }^{\circledR}$, Saint-Quentin Fallavier, France) at a flow rate of 1.5 L. $\min ^{-1}$. Three tubes were used for each sample for the reproducibility of the measures. Samples were analysed immediately after filling the Tenax tubes with a PerkinElmer ${ }^{\circledR}$ ATD Turbomatrix automated thermal desorber (ATD; Waltham, MA, USA). In the second step, the cold trap (22 $\mathrm{cm} \times 0.53 \mathrm{~mm}$ (i.d.); Supelco) was programmed to increase in temperature from $5{ }^{\circ} \mathrm{C}$ to $280{ }^{\circ} \mathrm{C}$ at $40{ }^{\circ} \mathrm{C} \mathrm{s}^{-1}$, after which it was isothermally held at $280{ }^{\circ} \mathrm{C}$ for $3 \mathrm{~min}$. The compounds were desorbed to the chromatograph with $\mathrm{H}_{2}$ as carrier gas through a heated transfer line maintained at $280^{\circ} \mathrm{C}$. A Perkin Elmer Clarus 500 (Waltham, MA, USA) GC-MS apparatus was used to identify the chemical compounds. The identification and quantification methods are detailed in a previous study [7]. 


\section{Results and discussion}

\subsection{Thermal properties}

Two important parameters of burning, namely ignition time and HRR were investigated. Both ignition time and HRR curve allow distinguishing three burning phases during these experiments: the pre-ignition phase, the flaming phase and the glowing phase associated with the combustion of carbon residues. It is useful to know the duration of each phase since the chemical compounds emitted differ as function of the phases. For instance, a longer ignition time results in a higher emission of tar compounds in this phase.

Figure 4 presents the ignition time of fern leaves and stems according to their stage of development. Three tests were done for each characteristic thickness (leaves or stems) of the samples and each state (dead or alive) for a total of 12 tests. The repeatability was very good as can be shown on the figure where the standard deviations are plotted. The ignition time of dead and alive leaves is respectively equal to 5.0 and $7.3 \mathrm{~s}$. The alive leaves ignite therefore slightly later than dead ones. In comparison, the alive leaves of Cistus monspeliensis [28] had an average ignition time of $5.3 \mathrm{~s}$, that is close to the ignition times of the fern regardless of its physiological stage. Indeed, their thicknesses are close $(0.5 \pm 0.1 \mathrm{~mm}$ for the fern against 0.75 $\pm 0.1 \mathrm{~mm}$ for the Cistus monspeliensis) and characteristics of thermally fine fuels. This explains why their ignition time are similar. The ignition time of the alive fern stems coincides with the ignition times of the Cistus twigs [28] having a diameter of $1 \mathrm{~mm}\left(t_{i g} \sim 22 \mathrm{~s}\right)$ although the fern diameter is more important $(5 \mathrm{~mm})$. We also note that the ignition time of dead fern stems is even lower and it understood between to the ignition time of Cistus leaves $(0.75 \mathrm{~mm})$ and that of twigs $1 \mathrm{~mm}$ in diameter In comparison, for a same diameter $(5 \mathrm{~mm})$, the ignition time of Cistus twigs is $48 \mathrm{~s}$ [27]. The differences of ignition times between the stem fern and the Cistus twigs comes from the structures of the stems and twigs (Fig. 5) and the heat transfer inside these particles. The radiant panel of the cone heats the upper face of the stems and twigs, whose surface and internal temperature increase. The fern stems (Fig. 5) are more or less hollow inside (porous) depending on the physiological state of the plant, unlike the Cistus branches which are full [8]. 


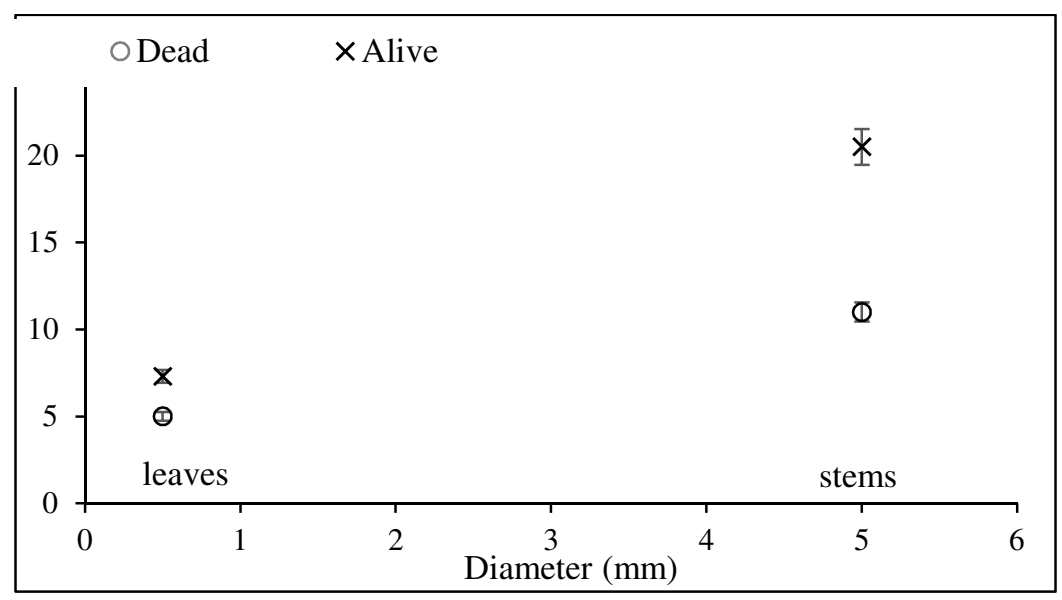

Figure 4. Average ignition time $t_{i g}$ and standard deviation depending on the characteristic thickness and physiological stage of the samples (dead or alive).

As the stems of the ferns are hollow (dead and alive) this slows the conduction inside their thickness. The internal air acts as an insulator, which promotes the rise in temperature of the outer layer and accelerates its thermal degradation. Conversely, the conduction inside the twigs branches will slow down the rise in temperature of their outer layer. Their degradation is slower than the stems of ferns one and they ignite later.

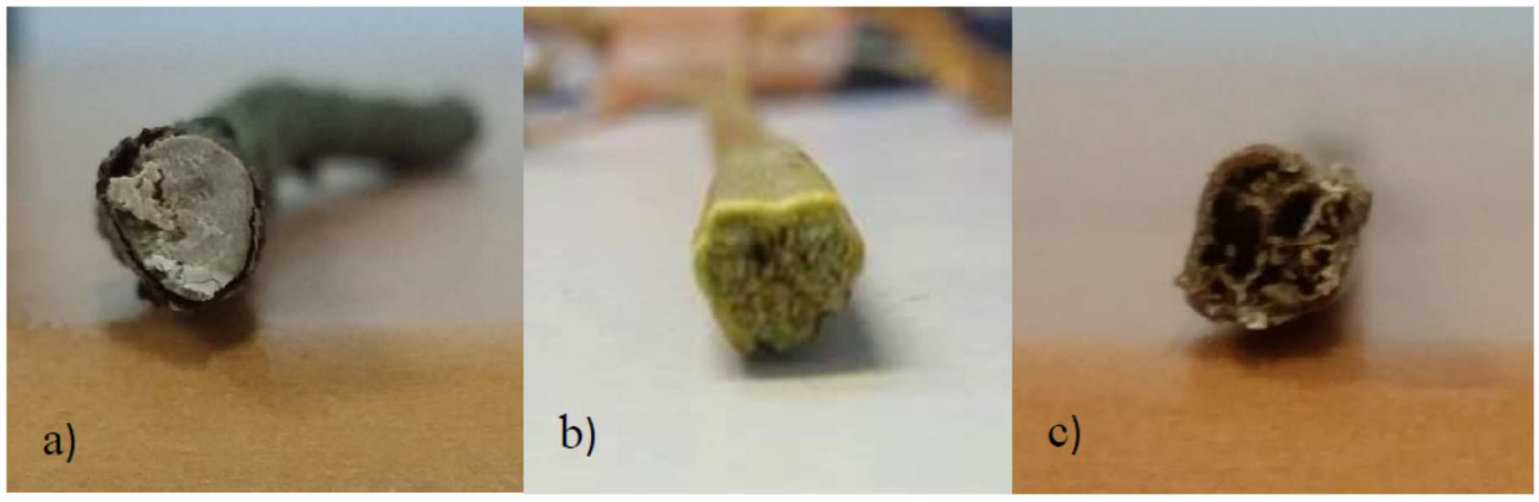

Figure 5. Pictures of the fuel particles with diameter $5 \mathrm{~mm}$ : a) Cistus twig [27], b) stem of alive fern, c) stem of dead fern.

Figure 6 shows the averaged heat release rate (HRR) per square meter over time for leaves and stems according to the physiological conditions (dead or alive). The HRR curves have been smoothed, and three replicates were done. From these curves, several phenomena can be highlighted. First, HRR curves are shifted in time. This is due to differences in the ignition times. The beginning of the heat release corresponds to the moment of flame appearance. $\mathrm{We}$ also observe a change in the shape of the curves. For the leaves, the degradation involves the whole volume of the fuel (low thickness) which has reached a sufficient temperature to degrade. 
This explains a single peak of HRR. As regard to the stems, we clearly distinguish two peaks of HRR with different intensities (the first peak is always stronger than the second one), and a plateau appears in between the peaks (Fig.6). At the beginning of the burning, the upper side of the stems is degraded and emits combustible gases. The flames are only visible above the fuel and the first peak of HRR corresponds to the maximum combustible rate of gaseous emission. Then, a plateau of HRR ensues which corresponds to a stable combustion that settles on the sides of the stems. During this period, the burning occurs along the sides of the hollow ferns, driven by the radiation coming from the cone heater and flame. Afterwards, a second peak of HHR occurs as the degradation reaches the back side of the fuel. For the alive stems, the first peak reaches $404 \mathrm{~kW} . \mathrm{m}^{-2}$ and the second one $394 \mathrm{~kW} \cdot \mathrm{m}^{-2}$. For the dead stems, the first peak is equal to $554 \mathrm{~kW} . \mathrm{m}^{-2}$ and the second one $431 \mathrm{~kW} . \mathrm{m}^{-2}$. In forest fire spread models the thickness of the particles of vegetation is a characteristic dimension that determines if they belong to the classes of particles involved in the dynamic of the fire front (active fire front). According to the literature, authors considered that twigs with diameter lower than $6 \mathrm{~mm}$ [24] or $4 \mathrm{~mm}$ [9] should be considered as well as fine leaves. The present work shows that the characteristic thickness of the samples is not the diameter for particles whose inside is porous like the stems of fern. In that case further study is necessary to confirm that the outer envelope of the stem could be this characteristic dimension.
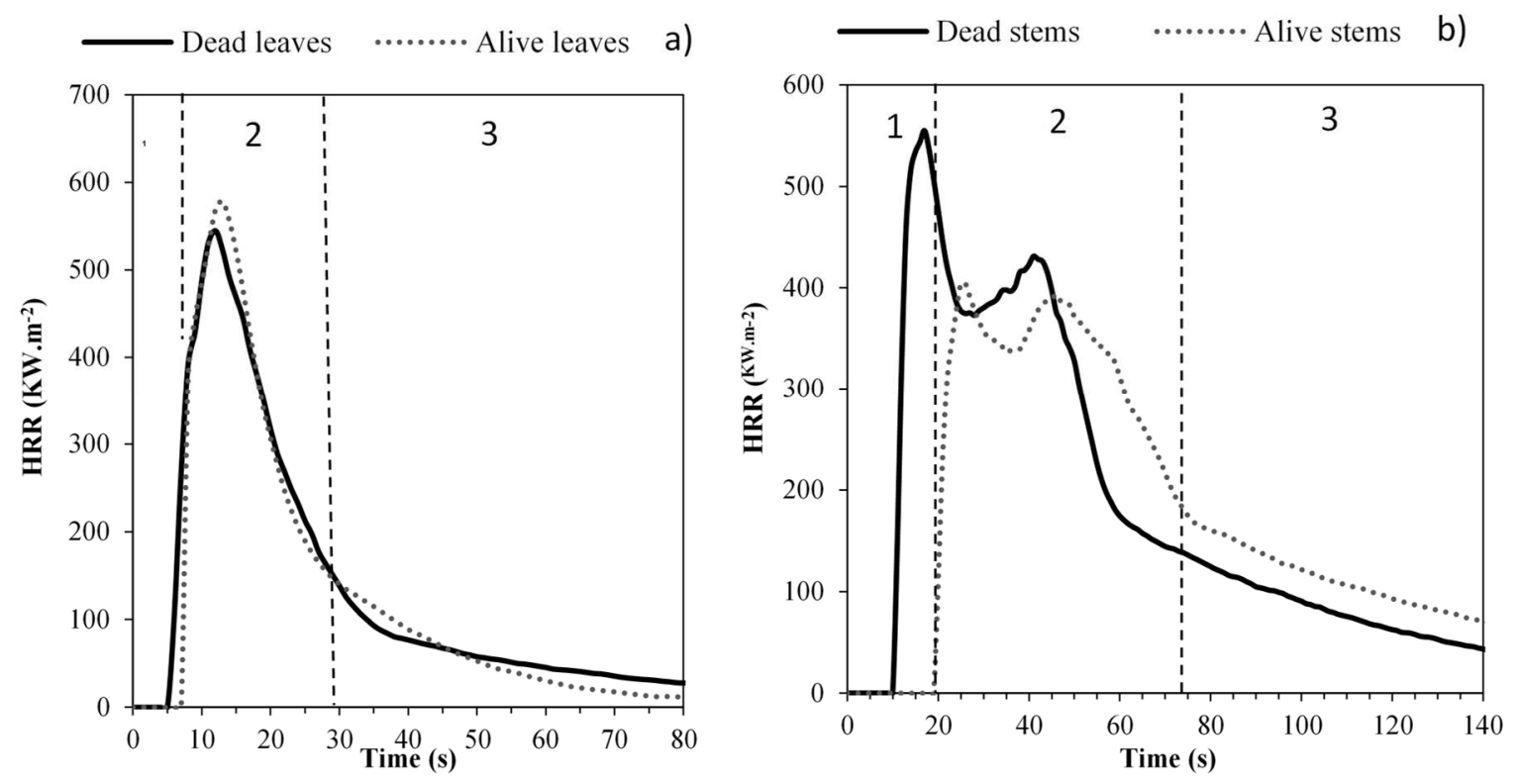

Figure 6. Comparison of mean HRR for a) dead and alive leaves of fern b) bead and alive stems of fern. The vertical lines represent ignition and flameout times for the alive leaves and stems (1: pre-ignition, 2: flaming and 3: glowing phases). 


\subsection{Smoke production}

Figure 7 shows averaged curves of SPR and HRR for the leaves and stems of fern. The SPR curves show good reproducibility. We only present the results for dead leaves and stems since there is no significant difference in the SPR and the dynamics of HRR (excepted ignition time) according to the state of the plant (alive or dead). A peak occurs on SPR at ignition. The SPR peaks reach $6 \times 10^{-2} \pm 1.5 \times 10^{-2} \mathrm{~m}^{2} \cdot \mathrm{s}^{-1}$ for fern leaves and $1.1 \times 10^{-1} \pm 1.5 \times 10^{-2} \mathrm{~m}^{2} . \mathrm{s}^{-1}$ for stems. These SPR values are higher than those obtained for leaves of Cistus $\left(2.5 \times 10^{-2} \mathrm{~m}^{2} . \mathrm{s}^{-1}\right)$ or for Cistus twigs with $5 \mathrm{~mm}$ of diameter $\left(1.9 \times 10^{-2} \mathrm{~m}^{2} . \mathrm{s}^{-1}\right)$ [27]. These high values of SPR at ignition could be explained by two phenomena: a high surface-volume ratio of fern leaves $\left(9400 \mathrm{~m}^{-1}\right)$ and the fact that their stems are hollow. In addition, they participate to a faster emission of the smokes before ignition and almost more during the flaming stage. The pre-ignition phase is the most important in terms of smoke production. Therefore, it has to be considered in the models of smoke production used in forest fire spread models. After ignition, during the flaming stage, the SPR decreases. For leaves, the value of SPR remains low (around $1 \times 10^{-3} \mathrm{~m}^{2} . \mathrm{s}^{-1}$ ) and the phase is very short (less than 15 seconds). Over the duration of the flaming stage, the averaged smoke production rate $\left(\mathrm{SPR}_{\mathrm{av}}\right)$ is equal to $4.5 \times 10^{-4} \mathrm{~m}^{2} \cdot \mathrm{s}^{-1}$. This value is lower than that obtained for Cistus leaves $\left(\mathrm{SPR}_{\mathrm{av}}=4.0 \times 10^{-3} \mathrm{~m}^{2} \cdot \mathrm{s}^{-1}\right)$ or for pine needles $\left(\mathrm{SPR}_{\mathrm{av}}=8.9 \times 10^{-3} \mathrm{~m}^{2} \cdot \mathrm{s}^{-1}\right)[5]$. For stems, a second steady-state peak appears during this stage. The SPR peak during the flaming stage reaches $6.6 \times 10^{-2} \mathrm{~m}^{2} \cdot \mathrm{s}^{-1}$. The averaged value of SPR during this stage is around $1.5 \times 10^{-2} \pm 0.5 \times 10^{-2} \mathrm{~m}^{2} . \mathrm{s}^{-1}$ for stem of fern vs. $6 \times 10^{-3} \pm 1 \times 10^{-3} \mathrm{~m}^{2} . \mathrm{s}^{-1}$ for Cistus twigs with a diameter of $5 \mathrm{~mm}$. The alveolar structure of the fern rods induces not only faster ignition but also faster internal stem degradation. The ensuing mixture of ambient air / degradation gas may be rich and leads to a less complete combustion, what generates more unburnt products.
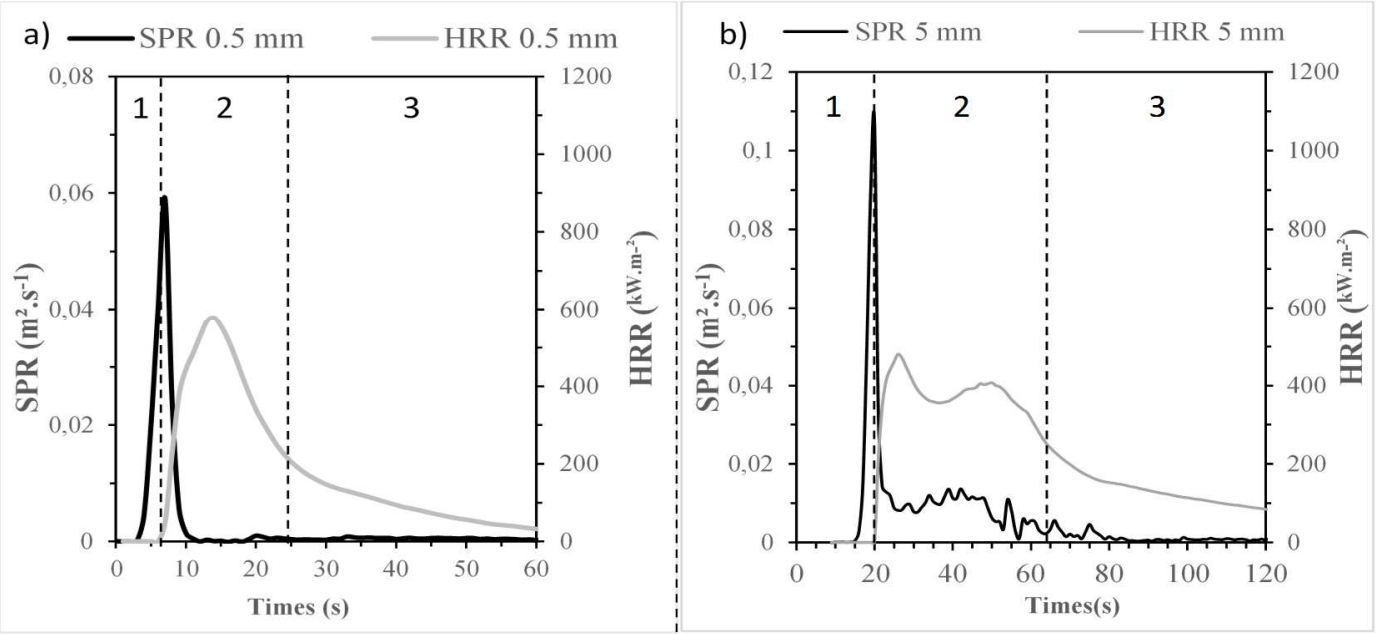
Figure 7. Averaged SPR and HRR curves for a) dead leaves ( $0.5 \mathrm{~mm}$ thick) of fern b) dead stems (5 mm thick) of fern. The vertical lines represent ignition and flameout times (1: preignition, 2: flaming and 3: glowing phases).

The TSP produced by the fern is equal to $0.27 \pm 0.03 \mathrm{~m}^{2}$ for the leaves, and to $0.69 \pm$ $0.12 \mathrm{~m}^{2}$ for the stems. This last value is greater than that of Cistus twigs with a same diameter, ie $5 \mathrm{~mm}\left(0.55 \pm 0.16 \mathrm{~m}^{2}\right)$ [27].

For the pre-ignition phase, the averaged SEA peak calculated for fern leaves reaches $310.5 \pm 117.3 \mathrm{~m}^{2} \cdot \mathrm{kg}^{-1}\left(317.2 \pm 139.2 \mathrm{~m}^{2} \cdot \mathrm{kg}^{-1}\right.$ for dead fern and $297.2 \pm 78.7 \mathrm{~m}^{2} \cdot \mathrm{kg}^{-1}$ for alive fern), which is on the same order as the value obtained for the leaves of Cistus $316.2 \pm 90.3$ $\mathrm{m}^{2} \cdot \mathrm{kg}^{-1}$ [27]. The averaged SEA peak reaches $424.5 \pm 97.5 \mathrm{~m}^{2} \cdot \mathrm{kg}^{-1}$ for stems $(411.6 \pm 102.8$ $\mathrm{m}^{2} \cdot \mathrm{kg}^{-1}$ and $432.2 \pm 105.6 \mathrm{~m}^{2} \cdot \mathrm{kg}^{-1}$ for dead and alive fern stems, respectively). These values coincide with those obtained for the Cistus twigs [27]. During the flaming stage, the SEA is stable and lower for the leaves $\left(8.56 \pm 6.82 \mathrm{~m}^{2} \cdot \mathrm{kg}^{-1}\right)$ than for the stems $\left(24.1 \pm 11.2 \mathrm{~m}^{2} \cdot \mathrm{kg}^{-1}\right)$. These values correspond to the SEA values obtained for the cistus leaves and twigs [27].

We chemically analysed the compounds emitted from leaves and stems of fern (dead and alive) during combustion, according to the burning phase. We first quantified elemental carbon (EC) and organic carbon (OC) in the aerosols emitted during the combustion of the ferns samples (mixed leaves and stems) in the calorimeter cone (Fig. 3). These analyses were carried out by the Analytice ${ }^{\circledR}$ company (according to the NIOSH 5040 method) using a technique that combines evolutionary thermal optical analysis (TOA) and flame ionisation detection (FID). Table 3 summarises the amounts of organic carbon, as well as the elemental and total carbon produced by ferns. Organic carbon (OC) represents $73.88 \%$ of the aerosols emitted. We calculated the OC/EC ratio in order to compare our results with those in the literature. This ratio is equal to 2.83 for this study. Fairly disparate OC/EC values are reported in the literature. They range from 1.2 [29] to 9.6 [30] for forest fuel burned in laboratory experiments, while another laboratory study using different forest fuels provided OC/EC ratios between 7.83 and 56, with a value of 13.2 for maquis-type fuels [31]. Values greater than unity are common for biomass combustion [32]. 
Table 3. OC and EC quantities $(\mu \mathrm{g})$ present in the aerosols emitted during the combustion of fern samples.

\begin{tabular}{cc}
\hline & Mass $(\boldsymbol{\mu g})$ \\
\hline OC & 990 \\
\hline EC & 350 \\
\hline TC & 1340 \\
\hline
\end{tabular}

Figure 8 displays the emission factors (EFs) of the main gases and aerosols emitted during fuel combustion, namely $\mathrm{CO}_{2}, \mathrm{CO}$, aerosols $(\mathrm{PM}), \mathrm{NO}$, sulphur dioxide $\left(\mathrm{SO}_{2}\right)$ and hydrochloric acid $(\mathrm{HCl})$. Differences are observed depending on its dead or alive development cycle (Fig.

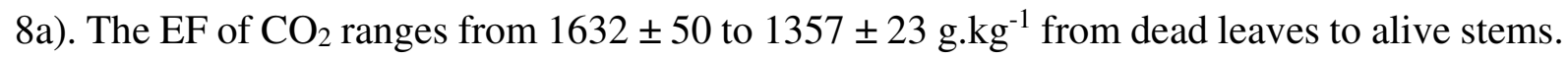
The mean EF of $\mathrm{CO}_{2}$ is equal to $1615 \pm 29 \mathrm{~g} \cdot \mathrm{kg}^{-1}$ for dead fern. The alive ferns have mean EF of $1423 \pm 76$ g. $\mathrm{kg}^{-1}$. This may be due to the amount of carbon in the fuel, which is lower for alive ferns $(47.7 \%)$ than for dead ferns $(50.3 \%)$.

We note that these EFs are in agreement with the literature. Indeed, the literature reveals total $\mathrm{EF}$ of $1550 \pm 95 \mathrm{~g} \cdot \mathrm{kg}^{-1}$ [3], $1538 \pm 125 \mathrm{~g} \cdot \mathrm{kg}^{-1}$ [31], $1565 \pm 128 \mathrm{~g} \cdot \mathrm{kg}^{-1}$ [33], $1712 \pm 66 \mathrm{~g} \cdot \mathrm{kg}^{-1}$ [34], and $1793 \pm 12$ g. $\mathrm{kg}^{-1}$ [30] in laboratory experiments for $\mathrm{CO}_{2}$. EF according to the combustion phase reveals that $\mathrm{CO}_{2}$ is mainly emitted during the flaming stage, at $63.2 \%$ and to a lesser extent during the glowing phase, at $32.8 \%$. The $\mathrm{EF}$ of $\mathrm{CO}$ is different depending on the fern part (leaves or stems) and the physiological conditions (dead or alive) (Fig. 8b). EF are equal to $129.9 \pm 3.4$ g. $\mathrm{kg}^{-1}$ and $148.7 \pm 10.1$ g. $\mathrm{kg}^{-1}$ for leaves and stems from alive ferns and $69.4 \pm 18.0 \mathrm{~g} \cdot \mathrm{kg}^{-1}$ and $117.0 \pm 14.1 \mathrm{~g} \cdot \mathrm{kg}^{-1}$ for leaves and stems from dead fern. CO is mainly emitted during the glowing phase, at $86.9 \%$ whereas the part emitted in the flaming stage corresponds to $11.9 \%$. The values of the emission factors obtained for $\mathrm{CO}$ are in agreement with the literature in which a great variability of values are reported. Values recorded in laboratory experiments are: $78 \pm 31$ g.kg-1 [3], $93.2 \pm 24.1$ g. $\mathrm{kg}^{-1}$ [31], $50.3 \pm 17.1$ g.kg ${ }^{-1}$ [33] and $55.5 \pm 7.7$ g. $\mathrm{kg}^{-1}$ [34], while values recorded during field campaigns (in the case of bushtype fires) are $69.7 \pm 6.17$ g. $\mathrm{kg}^{-1}$ [35], $69 \pm 17 \mathrm{~g} \cdot \mathrm{kg}^{-1}$ [36], $35 \mathrm{~g} . \mathrm{kg}^{-1}$ [4], $67 \pm 13 \mathrm{~g} \cdot \mathrm{kg}^{-1}$ [37], and $73.8 \pm 18.4$ g. $\mathrm{kg}^{-1}[38]$. We found a greater proportion of $\mathrm{CO}$ during the glowing phase for alive ferns 139.3 g. $\mathrm{kg}^{-1}$ compared to dead fern $93.2 \mathrm{~g} \cdot \mathrm{kg}^{-1}$. So, the alive ferns produce more CO in the glowing phase. It would therefore tend to produce more char than the other fuels studied. It also explains why its $\mathrm{CO}_{2}$ emission factor during the flaming phase is low. The third most important constituent in smoke are aerosols (Fig. 8c). During the pre-ignition phase, the aerosols are the third compounds emitted after $\mathrm{CO}_{2}$ and $\mathrm{H}_{2} \mathrm{O}$. It is the most important 
combustible compound during this phase (from 6.2 to 13 g.kg-1). It certainly contributes to the ignition of the mixture by lowering its lower flammability limit. The EF of aerosols range from 9.3 to 14.3 g.kg-1 for the whole burning stages. There is no significant difference between leaves and stems or between the vegetative stages of the plant. For alive ferns samples, the EFs are $12.7 \pm 1.7 \mathrm{~g} . \mathrm{kg}^{-1}$ and $14.3 \pm 6.5 \mathrm{~g} . \mathrm{kg}^{-1}$ respectively for leaves and stems. For dead ferns samples, values reach $13.1 \pm 0.9$ g. $\mathrm{kg}^{-1}$ and $9.3 \pm 0.9 \mathrm{~g} . \mathrm{kg}^{-1}$ for leaves and stems, respectively. These values are in agreement with the literature, which reports values that range from $7.2 \pm$ 2.3 g. $\mathrm{kg}^{-1}$ [3] to $11.6 \pm 6.9$ g. $\mathrm{kg}^{-1}[31,39]$ for laboratory experiments, while Garcia-Hurtado et al., [40] and Alves et al., [4] provide almost identical values of 3.4 and $3.5 \mathrm{~g} . \mathrm{kg}^{-1}$ for Mediterranean maquis fires. The EF of aerosols is greater during the pre-ignition phase. We obtained the following distribution: $86.4 \%$ during the pre-ignition phase, $9.7 \%$ during the flaming phase and $3.9 \%$ during the glowing phase.

NO is the fourth constituent present in the smoke (Fig. 8d). The EF of NO range from $1.9 \pm$ 0.6 g. $\mathrm{kg}^{-1}$ to $4.9 \pm 1.3 \mathrm{~g} \cdot \mathrm{kg}^{-1}$. The EF of NO is more important for the leaves than for the stems. It is mainly emitted in the flaming phase at $60 \%$ and at $38 \%$ in the glowing phase. The EF of NO is very high because nitrogen is present in high concentrations in the plant (Table 1, 0.6\% in dead fern and $3.3 \%$ in alive fern). These results are slightly higher than those found in literature because of the high nitrogen content of the fern. Andrae and Merlet [3] reported FE of NOx at $1.1 \pm 0.6$ g.kg-1 $2.2 \pm 2.2$ g.kg-1 [31], $2.74 \pm 0.75$ g.kg-1 [33] and $4.39 \pm 2.4 \mathrm{~g}^{-1} \mathrm{~kg}^{-1}$ [34]. $\mathrm{SO}_{2}$ is the fifth constituent present in the smoke emitted by the fern combustion (Fig. 8e). The $\mathrm{EF}$ of $\mathrm{SO}_{2}$ range from $0.6 \pm 0.2 \mathrm{~g} . \mathrm{kg}^{-1}$ to $3.8 \pm 1.4 \mathrm{~g} . \mathrm{kg}^{-1}$ depending on the parts of the plant and the physiological stage. This content is very important, and significantly higher than those found in the literature. EF reported by the authors are between $0.2 \pm 0.3 \mathrm{~g} \cdot \mathrm{kg}^{-1}$ [3] and $0.4 \pm 0.2$ g.kg- [31] at laboratory scale and between $0.2 \mathrm{~g}^{-1} \mathrm{~kg}^{-1}$ [4] and $0.7 \mathrm{~g} \cdot \mathrm{kg}^{-1}$ [37] for field experiments. The high levels of $\mathrm{SO}_{2}$ obtained in our study can be explained by the composition of the fern. The ultimate analysis reveals the presence of sulfur in a very high proportion: $0.22 \%$ for alive fern and $0.06 \%$ for dead fern. These high levels of $\mathrm{SO}_{2}$ may be responsible during the prescribed burning of the strong irritation felt by firefighters. Even in low concentrations, sulfur dioxide is an irritating gas in the nose and upper airways. Sulfur dioxide is corrosive to the eyes and skin. $\mathrm{SO}_{2}$ is mainly emitted during the glowing phase (60\%). During the flaming stage and the pre-ignition phase, the proportion corresponds respectively to $34 \%$ and $6 \%$. To be protected against this gaseous compound in prescribed burnings and fires, the firefighters should not be exposed to the smokes at least during the glowing phase. The EF of $\mathrm{HCl}$ range from $0.1 \pm 0.2$ g. $\mathrm{kg}^{-1}$ to $1.6 \pm 1.0$ g. $\mathrm{kg}^{-1}$ depending on the parts of the plant and the physiological stage. This 
concentration of $\mathrm{HCl}$ is important because this compounds is responsible for acute intoxication, it is irritating to the skin and eyes. $\mathrm{HCl}$ is an acid and therefore corosive. $\mathrm{HCl}$ is mainly emitted during the glowing phase at 59\%, then during the flaming phase at $34 \%$ and during the preignition at $7 \%$.
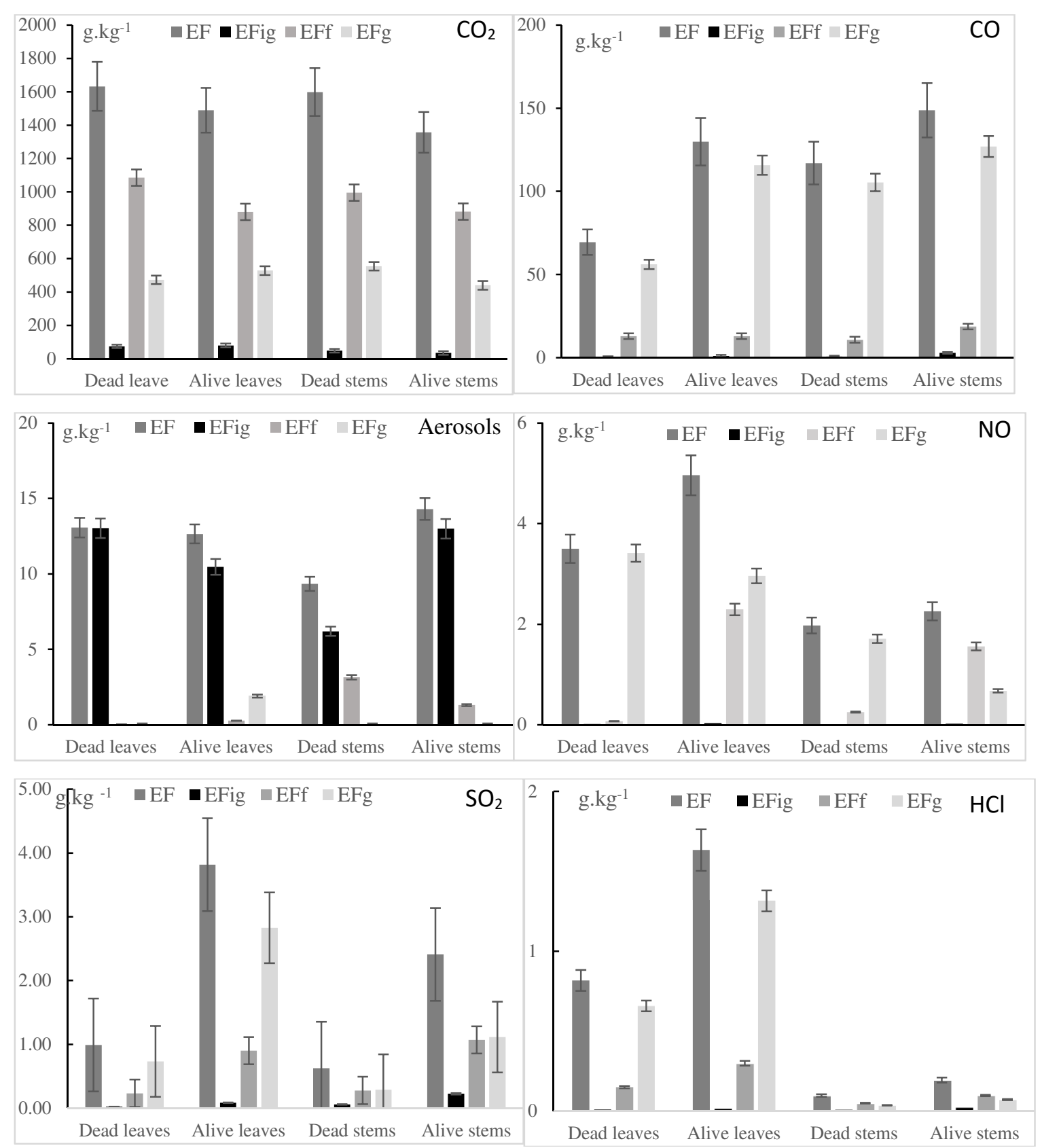

Figure 8. EFs of constituents according to the physiological stages and the fern part. EF: Total emission factor (sum of $\mathrm{EF}_{\mathrm{ig}}, \mathrm{EF}_{\mathrm{f}}$ and $\mathrm{EF}_{\mathrm{g}}$ ), $\mathrm{EF}_{\mathrm{ig}}$ : Emission factor during the pre-ignition phase, $\mathrm{EF}_{\mathrm{f}}$ : Emission factor during the flaming phase, $\mathrm{EF}_{\mathrm{g}}$ : Emission factor during the glowing phase. 
Table 4 lists the species identified and their total emission factors (leaves and stems averaged) as function of the physiological stage of the fern. 35 compounds were identified. The emission factors were calculated by averaging the results for all the samples according to the physiological stage of the fern (dead and alive). The total emission factors are provided without distinction between the pre-ignition, flaming and glowing phases. The $\mathrm{CO}$ and $\mathrm{CO}_{2}$ measurements were used to calculate the modified combustion efficiency (MCE). A mean value of 0.95 (dead fern) and 0.91 (alive fern) were obtained which indicates that the flame phase predominates. Our experiments reveal that the combustion is over-ventilated with the calorimeter coneWe observe the presence of compounds with nitrogen (compounds $\mathbf{1 5}$ to $\mathbf{1 8}$ and 29) in the combustion of fern as well as hydrocarbons. The EF of $\mathrm{NH}_{3}\left(0.3 \pm 0.3 \mathrm{~g} . \mathrm{kg}^{-1}\right.$ for the dead fern and $0.6 \pm 0.5 \mathrm{~g} . \mathrm{kg}^{-1}$ for alive fern $)$ and $\mathrm{HCN}\left(0.1 \pm 0.02 \mathrm{~g} . \mathrm{kg}^{-1}\right.$ for the dead fern and $0.2 \pm 0.02{\mathrm{~g} . \mathrm{kg}^{-1}}^{-1}$ for alive fern) is explained by the composition of the fern. The ultimate analysis has indeed revealed the presence of nitrogen in a high proportion (Table 1 gives 3.3\% for the alive fern and $0.6 \%$ for the dead fern) for both. $\mathrm{SO}_{2}, \mathrm{HCl}$ and $\mathrm{NH}_{3}$ are responsible for the irritant nature, whereas $\mathrm{HCN}$ is responsible for the asphyxiating nature of the effluents from burning fern felt by firefighters during prescribed burnings. The $\mathrm{EF}$ of the $\mathrm{NH}_{3}$ are in agreement with the literature. The authors give indeed the $\mathrm{EF}$ of $\mathrm{NH}_{3}$ equal to $1.3 \mathrm{~g} \cdot \mathrm{kg}^{-1}[3], 1.5 \pm 1.3 \mathrm{~g} \cdot \mathrm{kg}^{-}$ ${ }^{1}$ [31] and $0.2 \pm 0.1$ g.kg-1 [34] for laboratory experiments and $1.3 \mathrm{~g}^{-1} \mathrm{~kg}^{-1}$ [4], $1.0 \pm 0.7 \mathrm{~g} . \mathrm{kg}^{-1}$ [37] and $1.5 \pm 1.4$ g.kg ${ }^{-1}$ [38] for field experiments. Benzene and toluene are the most emitted non-methane organic compounds (NMOCs), with a mean emission factor of $97.7 \mathrm{mg} \cdot \mathrm{kg}^{-1}$. This result is consistent with the work of Romagnoli et al., [34] (98 \pm 3 mg.kg ${ }^{-1}$ ) and Aurell et al., [30] $\left(92 \pm 20 \mathrm{mg} \cdot \mathrm{kg}^{-1}\right)$. On the other hand, it is somewhat lower than the values proposed by Urbanski et al., [36] (220 mg.kg-1) and Yokelson et al., [38] (451 $\left.\pm 287 \mathrm{mg} . \mathrm{kg}^{-1}\right)$ for temperate and semi-arid scrub fires.

TEXS (toluene, ethylbenzene, xylenes and styrene) are also present as well as furan and its derivatives. We also note the presence of volatile PAH (naphthalene) in low proportion.

Table 4. Mean EF ( $\left.\mathrm{g} \cdot \mathrm{kg}^{-1}\right)$ of compounds identified in the smoke during the combustion of the fern.

\begin{tabular}{cccc}
\hline $\mathrm{N}^{\circ}$ & Compounds & \multicolumn{2}{c}{$\mathrm{EF}\left({\left.\mathrm{g} . \mathrm{kg}^{-1}\right)}\right.$} \\
\hline & IRND & Dead & Alive \\
\hline 1 & $\mathrm{CO}_{2}$ (carbon dioxide) & $1615 \pm 29$ & $1423 \pm 76$ \\
\hline 2 & $\mathrm{CO}$ (carbon monoxide) & $93.2 \pm 29.8$ & $139.3 \pm 12.5$ \\
\hline 3 & Laser He-Ne & $11.2 \pm 2.6$ & $13.5 \pm 1.2$ \\
\hline & Aerosols & \\
\hline
\end{tabular}




\begin{tabular}{|c|c|c|c|}
\hline 4 & $\mathrm{H}_{2} \mathrm{O}$ (water) & $527.6 \pm 72.6$ & $419.7 \pm 52.0$ \\
\hline 5 & $\mathrm{CH}_{4}$ (methane) & $0.6 \pm 0.6$ & $1.6 \pm 1.1$ \\
\hline 6 & $\mathrm{C}_{2} \mathrm{H}_{6}$ (ethane) & $0.03 \pm 0.01 *$ & $0.05 \pm 0.01 *$ \\
\hline 7 & $\mathrm{C}_{3} \mathrm{H}_{8}$ (propane) & $0.2 \pm 0.1$ & $0.3 \pm 0.1$ \\
\hline 8 & $\mathrm{C}_{5} \mathrm{H}_{12}$ (pentane) & $0.1 \pm 0.01$ & $0.1 \pm 0.01$ \\
\hline 9 & $\mathrm{C}_{2} \mathrm{H}_{4}$ (ethene) & $0.7 \pm 0.6$ & $0.7 \pm 0.6$ \\
\hline 10 & $\mathrm{C}_{3} \mathrm{H}_{6}$ (propene) & $0.7 \pm 0.4$ & $0.7 \pm 0.4$ \\
\hline 11 & $\mathrm{C}_{4} \mathrm{H}_{6}(1,3$-butadiene $)$ & $0.4 \pm 0.2 *$ & $0.4 \pm 0.2 *$ \\
\hline 12 & $\mathrm{C}_{2} \mathrm{H}_{2}$ (acetylene) & $0.2 \pm 0.1$ & $0.2 \pm 0.1$ \\
\hline 13 & $\mathrm{CH}_{2} \mathrm{O}$ (formaldehyde) & $0.8 \pm 0.2$ & $0.8 \pm 0.1$ \\
\hline 14 & $\mathrm{C}_{2} \mathrm{H}_{4} \mathrm{O}$ (Acetaldehyde) & $0.8 \pm 0.6^{*}$ & $1.1 \pm 0.2^{*}$ \\
\hline 15 & HCN (cyanhydric acid) & $0.1 \pm 0.02 *$ & $0.2 \pm 0.02 *$ \\
\hline 16 & NO (nitrogen monoxide) & $2.7 \pm 0.8$ & $3.8 \pm 2.1$ \\
\hline 17 & $\mathrm{NO}_{2}$ (nitrogen dioxide) & $0.2 \pm 0.02$ & $0.2 \pm 0.02$ \\
\hline 18 & $\mathrm{NH}_{3}$ (ammonia) & $0.3 \pm 0.3$ & $0.6 \pm 0.5$ \\
\hline 19 & $\mathrm{SO}_{2}$ (sulphur dioxide) & $0.8 \pm 0.3$ & $3.1 \pm 1.0$ \\
\hline 20 & $\mathrm{HCl}$ (hydrochloric acid) & $0.5 \pm 0.5$ & $0.9 \pm 1.0$ \\
\hline & DTA/GC-MS & \multicolumn{2}{|c|}{$\times 10^{-3}$} \\
\hline 21 & $\mathrm{C}_{6} \mathrm{H}_{14}$ (n-hexane) & $32 \pm 2.4$ & $40 \pm 3.1$ \\
\hline 22 & $\mathrm{C}_{7} \mathrm{H}_{16}$ (heptane) & $4.3 \pm 2.4$ & $7.4 \pm 3.2$ \\
\hline 23 & $\mathrm{C}_{6} \mathrm{H}_{6}$ (benzene) & $97.2 \pm 2.8$ & $98.1 \pm 2.1$ \\
\hline 24 & $\mathrm{C}_{7} \mathrm{H}_{8}($ toluene $)$ & $91.0 \pm 3.1$ & $68.8 \pm 6.4$ \\
\hline 25 & $\mathrm{C}_{8} \mathrm{H}_{10}$ (ethyl-benzene) & $15.1 \pm 1.2$ & $16.3 \pm 7.8$ \\
\hline 26 & $\mathrm{C}_{8} \mathrm{H}_{10}(\text { xylenes })^{\mathrm{i}}$ & $8.1 \pm 3.6$ & $7.9 \pm 2.5$ \\
\hline 27 & $\mathrm{C}_{8} \mathrm{H}_{8}$ (styrene) & $4.5 \pm 2.7$ & $13.1 \pm 5.3$ \\
\hline 28 & $\mathrm{C}_{7} \mathrm{H}_{6} \mathrm{O}$ (benzaldehyde) & $2.1 \pm 1.1$ & $3.3 \pm 2.4$ \\
\hline 29 & $\mathrm{C}_{6} \mathrm{H}_{6} \mathrm{O}$ (phénol) & $3.6 \pm 2.3$ & $2.4 \pm 2.0$ \\
\hline 30 & $\mathrm{C}_{4} \mathrm{H}_{5} \mathrm{~N}$ (pyrrol) & $11.4 \pm 4.4$ & $13.4 \pm 2.3$ \\
\hline 31 & $\mathrm{C}_{6} \mathrm{H}_{8} \mathrm{O}$ (dimethyl-furan) & $2.1 \pm 0.7$ & - \\
\hline 32 & $\mathrm{C}_{5} \mathrm{H}_{4} \mathrm{O}_{2}$ (furfural) & $11.4 \pm 4.8$ & $7.4 \pm 1.7$ \\
\hline 33 & $\mathrm{C}_{7} \mathrm{H}_{14} \mathrm{O}$ (heptanal) & $1.9 \pm 1.1$ & - \\
\hline 34 & $\mathrm{C}_{2} \mathrm{H}_{4} \mathrm{O}_{2}$ (acetic acid) & $4.4 \pm 2.6$ & $2.8 \pm 1.8$ \\
\hline 35 & $\mathrm{C}_{10} \mathrm{H}_{8}$ (naphthalene) & $4.1 \pm 1.7$ & $2.8 \pm 1.2$ \\
\hline
\end{tabular}

*only in leaves; ${ }^{\text {isomers; }}$ - not detected

Analyses of the products from fuel combustion reveal numerous carbonaceous compounds. A total carbon mass balance was performed in order to assess the quality of our analyses. The results are given in Table 5. The carbon mass balance provides a comparison between the amount of carbon present in the smoke and the amount of carbon available in the fuel, as determined by the ultimate analyses presented in Table 1 . 
The dead fern produced $492 \mathrm{~g}_{\mathrm{C}} \cdot \mathrm{kg}^{-1}$ (grams of carbon per kilogram of dry fuel burnt), and the alive fern $459 \mathrm{~g}_{\mathrm{C}} \cdot \mathrm{kg}^{-1}$. The total emitted carbon mass per kilogram of dry fuel burnt was calculated by summing the carbon identified in the gaseous and particulate phases (tars and soot). As reported previously [27], the major compound present in tars is levoglucosan. Consequently, we assumed that the tars were entirely composed of levoglucosan when determining the mass of carbon released in the tars. The soot was assumed to be pure carbon. $97.8 \%$ and $96.1 \%$ of the carbon was identified in the smoke during the combustion of dead and alive ferns respectively, with $87.6 \%$ and $81.4 \%$ of the carbon in the form of $\mathrm{CO}_{2}$ respectively for the dead and alive ferns, $7.9 \%$ and $12.5 \%$ from $\mathrm{CO}$ and $1.2 \%$ and $1.6 \%$ from aerosols (soot and tars). We observe that the sulfur present in the fern is only found in SO2 in the smoke with an average of $69 \%$ in this form. $\mathrm{Cl}$ which is found in $\mathrm{HCl}$ in the smoke with an average of $34 \%$ for this form. The rest of $\mathrm{S}$ and $\mathrm{Cl}$ could be in the ashes or volatile compounds not identified in this paper.

Table 5. Total carbon mass balance for the compounds analysed in smoke during the combustion of fern with a cone calorimeter.

\begin{tabular}{|c|c|c|}
\hline \multirow{2}{*}{$\begin{array}{c}\text { Compounds } \\
\text { IRND }\end{array}$} & \multicolumn{2}{|c|}{$\begin{array}{l}\text { Carbon mass per unit of dry fuel } \\
\text { burnt }\left(\mathrm{g}_{\mathrm{C}} \cdot \mathrm{kg}^{-1}\right)\end{array}$} \\
\hline & Dead & Alive \\
\hline $\mathrm{CO}_{2}$ (carbone monoxide) & $440.55 \pm 6.53$ & $388.10 \pm 25.35$ \\
\hline CO (carbone dioxide) & $39.94 \pm 1.55$ & $59.69 \pm 5.71$ \\
\hline \multicolumn{3}{|l|}{ Laser $\mathrm{He}-\mathrm{Ne}$} \\
\hline $\operatorname{tars} \mathrm{C}_{6} \mathrm{H}_{10} \mathrm{O}_{5}$ (levoglucosan) & $4.27 \pm 2.15$ & $5.21 \pm 0.80$ \\
\hline soot & $1.59 \pm 0.64$ & $0.79 \pm 0.73$ \\
\hline \multicolumn{3}{|l|}{ FTIR } \\
\hline $\mathrm{CH}_{4}$ (methane) & $0.855 \pm 0.765$ & $1.223 \pm 1.043$ \\
\hline $\mathrm{C}_{2} \mathrm{H}_{6}$ (ethane) & $0.024 \pm 0.008$ & $0.04 \pm 0.008$ \\
\hline $\mathrm{C}_{3} \mathrm{H}_{8}$ (propane) & $0.196 \pm 0.049$ & $0.213 \pm 0.049$ \\
\hline $\mathrm{C}_{5} \mathrm{H}_{12}$ (pentane) & $0.075 \pm 0.008$ & $0.075 \pm 0.008$ \\
\hline $\mathrm{C}_{2} \mathrm{H}_{4}$ (ethene) & $0.583 \pm 0.514$ & $0.617 \pm 0.694$ \\
\hline $\mathrm{C}_{3} \mathrm{H}_{6}$ (propene) & $0.617 \pm 0.351$ & $0.617 \pm 0.326$ \\
\hline $\mathrm{C}_{4} \mathrm{H}_{6}$ (butadiene) & $0.364 \pm 0.169$ & $0.364 \pm 0.151$ \\
\hline $\mathrm{C}_{2} \mathrm{H}_{2}$ (acetylene) & $0.157 \pm 0.092$ & $0.194 \pm 0.092$ \\
\hline $\mathrm{CH}_{2} \mathrm{O}$ (formaldehyde) & $0.316 \pm 0.068$ & $0.344 \pm 0.056$ \\
\hline $\mathrm{C}_{2} \mathrm{H}_{4} \mathrm{O}$ (acetaldehyde) & $0.458 \pm 0.071$ & $0.611 \pm 0.082$ \\
\hline HCN (cyanhydric acid) & $0.049 \pm 0.009$ & $0.098 \pm 0.009$ \\
\hline DTA/GC-MS & $\times 10^{-3}$ & \\
\hline $\mathrm{C}_{3} \mathrm{H}_{6}$ (propene) & $0.011 \pm 0.007$ & $0.014 \pm 0.006$ \\
\hline
\end{tabular}




\begin{tabular}{ccc}
\hline $\mathrm{C}_{6} \mathrm{H}_{14}$ (hexane) & $0.027 \pm 0.002$ & $0.033 \pm 0.003$ \\
\hline $\mathrm{C}_{7} \mathrm{H}_{16}$ (heptane) & $0.004 \pm 0.002$ & $0.006 \pm 0.003$ \\
\hline $\mathrm{C}_{6} \mathrm{H}_{6}$ (benzene) & $0.090 \pm 0.003$ & $0.091 \pm 0.002$ \\
\hline $\mathrm{C}_{7} \mathrm{H}_{8}$ (toluene) & $0.083 \pm 0.003$ & $0.063 \pm 0.006$ \\
\hline $\mathrm{C}_{8} \mathrm{H}_{10}$ (ethyl-benzene) & $0.014 \pm 0.001$ & $0.015 \pm 0.007$ \\
\hline $\mathrm{C}_{8} \mathrm{H}_{10}$ (xylenes) & $0.007 \pm 0.003$ & $0.007 \pm 0.002$ \\
\hline $\mathrm{C}_{8} \mathrm{H}_{8}$ (styrene) & $0.004 \pm 0.002$ & $0.012 \pm 0.005$ \\
\hline $\mathrm{C}_{7} \mathrm{H}_{6} \mathrm{O}$ (benzaldehyde) & $0.002 \pm 0.001$ & $0.003 \pm 0.002$ \\
\hline $\mathrm{C}_{6} \mathrm{H}_{6} \mathrm{O}$ (phenol) & $0.003 \pm 0.002$ & $0.002 \pm 0.001$ \\
\hline $\mathrm{C}_{4} \mathrm{H}_{5} \mathrm{~N}$ (pyrrol) & $0.010 \pm 0.004$ & $0.011 \pm 0.002$ \\
\hline $\mathrm{C}_{6} \mathrm{H}_{8} \mathrm{O}$ (dimethylfurane) & $0.002 \pm 0.001$ & - \\
\hline $\mathrm{C}_{5} \mathrm{H}_{4} \mathrm{O}_{2}$ (furfural) & $0.007 \pm 0.003$ & $0.005 \pm 0.001$ \\
\hline $\mathrm{C}_{7} \mathrm{H}_{14} \mathrm{O}$ (heptanal) & $0.001 \pm 0.001$ & - \\
\hline $\mathrm{C}_{2} \mathrm{H}_{4} \mathrm{O}_{2}$ (acetic acid) & $0.003 \pm 0.002$ & $0.002 \pm 0.001$ \\
\hline $\mathrm{C}_{10} \mathrm{H}_{8}$ (naphthalene) & $0.004 \pm 0.002$ & $0.003 \pm 0.001$ \\
\hline Total carbon mass balance (smoke) & $\mathbf{4 9 2} \pm \mathbf{1 4}$ & $\mathbf{4 5 9} \pm \mathbf{3 5}$ \\
\hline Carbon total (ultimate analyses) & $\mathbf{5 0 3}$ & $\mathbf{4 7 7}$ \\
\hline \% of Carbon found & $\mathbf{9 7 . 8 \%}$ & $\mathbf{9 6 . 1 \%}$ \\
\hline
\end{tabular}

Compounds

Sulfur mass per unit of dry fuel burnt $\left(\mathrm{gs}_{\mathrm{sg}} \mathrm{kg}^{-1}\right)$

\begin{tabular}{ccc}
\hline Total sulfur mass balance (smoke) & 0.4 & 1.6 \\
\hline Sulfur total (ultimate analyses) & 0.6 & 2.2 \\
\hline \% of Sulfure found & $67.4 \%$ & $70.7 \%$ \\
\hline Compounds & $\begin{array}{c}\text { Chlorine mass per unit of dry fuel } \\
\text { burnt }\left(\mathrm{g}_{\mathrm{Cl}} \cdot \mathrm{kg}^{-1}\right)\end{array}$ \\
\hline Total chlorine mass balance (smoke) & 0.8 & 1.6 \\
\hline Chlorine total (ultimate analyses) & 2.5 & 4.3 \\
\hline \% of Chlorine found & $31.8 \%$ & $36.9 \%$ \\
\hline
\end{tabular}

\section{Conclusion}

The burning characteristics of alive and dead ferns were studied with a cone calorimeter. The thermal properties as well as the smoke constituent were determined according to the physiological stage of the fern for leaves and stems. The emission factors for aerosols, as well as carbonaceous and nitrogenous compounds, were determined by analytical methods. The main conclusions can be summarized as follows: 
- The analyses revealed a high concentration of $\mathrm{SO}_{2}$ and $\mathrm{HCl}$ emitted in the smoke that may be responsible during the prescribed burning of the strong irritation felt by firefighters. As $\mathrm{SO}_{2}$ and $\mathrm{HCl}$ are mainly emitted during the glowing stage, we recommend that firefighters should not be exposed to the smokes during this burning phase.

- A peak of SPR is observed at ignition. This peak is intense and related to the emission of aerosols.

- $\mathrm{CO}_{2}, \mathrm{H}_{2} \mathrm{O}, \mathrm{CO}$, aerosols, $\mathrm{NO}$, and $\mathrm{SO}_{2}$ are the major compounds emitted, with $\mathrm{EF}$ around 1615 g.kg-1 and 1423 g. $\mathrm{kg}^{-1}$ for $\mathrm{CO}_{2}$ from the dead and alive ferns respectively and 93 g. $\mathrm{kg}^{-1}$ and 139 g. $\mathrm{kg}^{-1}$ for $\mathrm{CO}$ from the dead and alive ferns respectively. Organic compounds (OC) are present in aerosols at higher levels than elemental carbon (EC). The ratio was equal to 2.8 .

○ We observed that aerosols are mainly emitted during the pre-ignition phase, while $\mathrm{CO}_{2}$, $\mathrm{H}_{2} \mathrm{O}$, and $\mathrm{NO}$ are mainly emitted during the flaming stage, whereas $\mathrm{CO}, \mathrm{NO}, \mathrm{SO}_{2}, \mathrm{CH}_{4}$, $\mathrm{HCl}$ and $\mathrm{NH}_{3}$ are mainly emitted during the glowing phase. Finally, we found that $97.8 \%$ and $96.1 \%$ of the carbon was identified in the smoke by comparison with the carbon content of the fuel determined by ultimate analysis.

\section{References}

[1] I. Dokas, M. Statheropoulos, S. Karma, Integration of field chemical data in initial risk assessment of forest fire smoke, Sci. Total Environ. 376 (2007) 72-85.

[2] T. Barboni, G. Pellizzaro, B. Arca, N. Chiaramonti, P. Duce, Analysis and origins of volatile organic compounds smoke from ligno-cellulosic fuels, J.Anal. Appl. Pyrol. 89 (2010) 6065

[3] M.O. Andreae, P. Merlet, Emission of trace gases and aerosols from biomass burning. Global Biogeochem. Cy. 15 (2001) 955-966.

[4] C.A. Alves, C. Gonçalves, C.A. Pio, F. Mirante, A. Caseiro, L. Tarelho, M.C. Freitas, D.X. Viegas, Smoke emissions from biomass burning in a Mediterranean shrubland. Atmos. Environ. 44 (2010) 3024-3033.

[5] P.A. Santoni, E. Romagnoli, N. Chiaramonti, T. Barboni, Scale effects on the heat release rate, smoke production rate, and species yields for a vegetation bed. J. Fire Sci. 33 (2015) 290-319.

[6] V. Tihay-Felicelli, P-A. Santoni, G. Gerandi, T. Barboni, Smoke emissions due to green waste burning in Mediterranean area: influence of fuel moisture content and fuel mass, Atmos. Environ. 159 (2017) 92-106 
[7] T. Barboni, M. Cannac, V. Pasqualini, A. Simeoni, E. Leoni, N. Chiaramonti, Volatile and semi-volatile organic compounds in smoke exposure of firefighters during prescribed burning in the Mediterranean region, Int. J. Wildland Fire 19 (2010) 606-612.

[8] T. Barboni, L. Leonelli, V. Tihay, P-A. Santoni, Influence of the particle size on the heat release rate and the smoke opacity during the burning of dead cistus at laboratory scale, J. Fire Sci. 35 (2017) 259-283

[9] A.I. Miranda, J. Ferreira, J. Valente, P. Santos, J.H. Amorim, C. Borrego, Smoke measurements during Gestosa-2002 experimental field fires, Int. J. Wildland Fire 14 (2005) $107-116$.

[10] C. Wiedinmyer, J.C. Neff Estimates of $\mathrm{CO}_{2}$ from fires in the United States: implications for carbon management, Carbon. Bal. Manage 2 (2007) 1-33.

[11] T. Barboni, N. Chiaramonti, BTEXs emissions according to the distance from the flame front and the combustion stages during the prescribed burning, Combust. Sci. Technol. 182 (2010) 1193-1200.

[12] M.Evtyugina, A. Alves, T. Nunes, L. Tarelho, M. Duarte, S.O. Prozil, C. Pio, VOC emissions from residential combustion of Southern and mid-European woods, Atmos. Environ. 83 (2014) 90-98.

[13] F. Reisen, S.K. Brown, Australian firefighters' exposure to air toxics during bushfire burns of autumn 2005 and 2006. Environ. Int. 35 (2009) 342-352.

[14] J.C. Slaughter , J.Q. Koenig, T.E. Reinhardt, Association between lung function and exposure to smoke among firefighters at prescribed burns, J. Occup. Enviro. Hyg. 1 (2004) $45-49$

[15] J. Malilay, A review of factors affecting the human health impacts of air pollutants from forest fires. In 'Health Guidelines for Vegetation Fire Events: Background Papers'. 1999, pp. 255-270. (World Health Organization, Geneva)

[16] T.E. Reinhardt, R.D. Ottmar, A. Hanneman, Smoke exposure among firefighters at prescribed burns in the Pacific Northwest. USDA Forest Service, Pacific Northwest Research Station, Research Paper PNW-RP-526, 2000, (Seattle, WA)

[17] C.T. Fowler, Human health impacts of forest fires in the southern United States: a literature review, Journal of Ecological Anthropology 7 (2003) 39-59

[18] T.Z. Fabian, J.L. Borgerson, P.D. Gandhi, C.S. Baxter, C.S. Ross, J.E. Lockey J.M. Dalton, Characterization of Firefighter Smoke Exposure, Fire Tech. 50 (2014) 993-1019

[19] J.C. Rameau, Flore forestière française tome 3 : Région méditerranéenne. Paris: Insitut pour le développement forestier, 2008.

[20] D.M. Potter, M.S. Baird, Carcinogenic effects of ptaquiloside in bracken fern and related compounds. British J. Cancer 83 (2000) 914-920.

[21]R.C. Peterssen, Chemical composition of wood, Chemistry of solid wood. Washington D.C.: Roxell R.M., 1984

[22] V. Babrauskas, Effective heat of combustion for flaming combustion of conifers, Can. J. Forest Res. 36 (2006) 659-663 
[23] H.E. Anderson, R.C. Rothermel, Influence of moisture and wind upon the characteristics of free-burning fires. Proceeding of the tenth Symposium (Internantional) on Combustion, 10 (1965) 1009-1019

[24] G. Cruz, B.W. Butler, D.X. Viegas, P. Palheiro, P., Characterization of flame radiosity in shrubland fires. Combust. Flame 158 (2011) 1970-1976

[25] N. Chiaramonti, E. Romagnoli, P-A. Santoni T. Barboni, Comparison of the thermal degradation of pine species, utilisation of two sizes of calorimeter: cone calorimeter and LSHR, Fire Technol. 53 (2017) 741-770

[26] B.A.L. Östman, L.D. Tsantardis, Smoke data from the cone calorimeter for comparison with the room fire test, Fire Mater. 17 (1993) 191-200.

[27] L. Leonelli, T. Barboni, P-A., Santoni, Y. Quilichini, A. Coppalle, Characterization of aerosols emissions from the combustion of dead shrub twigs and leaves using a cone calorimeter. Fire Safety J. 91 (2017) 800-810.

[28] V. Tihay-Felicelli, P-A. Santoni, L. Leonelli, T. Barboni, Study of the diameter influence on the autoignition of Cistus twigs: Ignition criterion and Modeling. Fire Thech. 52 (2016) 897-929.

[29] S. Hosseini, S.P. Urbanski, P. Dixit, L. Qi, I.R. Burling, R.J. Yokelson, T.J. Johnson, M. Shrivastava, H.S. Jung, E.R. Weise, J.W. Miller, D.R. Cocker, Laboratory characterization of PM emissions from combustion of wildland biomass fuels J. Geophysical Res. Atmos. 118 (2013) 9914-9929.

[30] J. Aurell, B.K. Gullett, D. Tabor, Emissions from southeastern U.S. Grasslands and pine savannas: Comparison of aerial and ground field measurements with laboratory burns. Atmos. Environ. 111 (2015) 170-178

[31] G.R. McMeeking, S.M. Kreidenweis, S. Baker, C.M. Carrico, J.C. Chow, J.L. Collett, W.M. Hao, A.M., Holden, T.W Kirchstetter, W.C. Malm, H. Moosmüller, A.P. Sullivan, C.E. Wold, Emission of trace gases and aerosols during the open combustion of biomass in the laboratory, J. Geophysical Res. 114 (2009) D19210

[32] J. Aurell, B. Gullett, D. Tabor, N. Yonker, Emissions from prescribed burning of timber slash piles in Oregon, Atmos. Environ. 150 (2017) 395-406

[33] T.G. Soares Neto, J.A. Jr. Carvalho, E.V. Cortez, R.G. Azevedo, R.A. Oliviera, W.R.R. Fidalgo, J.C. Santos, JLaboratory evaluation of Amazon forest biomass burning emissions Atmos. Environ. 45 (2011) 7455-7461.

[34] E.Romagnoli, T. Barboni, P-A. Santoni, N. Chiaramonti, Quantification of volatile organic compounds in smoke from prescribed burning and comparison with occupational exposure limits. Nat. Hazards and Earth Sys. 14 (2014) 1-9

[35] C.C. Hardy S.G. Conard J.C. Regelbrugge D.R. Teesdale, Smoke emissions from prescribed burning of southern California chaparral. Research paper, Forest Service, Pacific Northwest research station, Portland: United States Department of Agriculture 37 (1996).

[36] S.P. Urbanski, W.M. Hao, S. Baker, Chemical composition of wildland fire emissions.» Dans Developments in Enviromental Science, Volume 8, de A. Bytnerowicz, M. Arbaugh, A. Riebau et Andersen C., 79-107. 2009, Elsivier BV. 
[37] S.K. Akagi, R.J. Yokelson, C. Wiedinmyer, M.J. Alvarado, J.S. Reid, T. Karl, J.D. Crounse, P.O. Wennberg, Emission factors for open and domestic biomass burning for use in atmospheric models, Atmos. Chem. Phys 11 (2011) 4039-4072.

[38] R.J. Yokelson, I.R. Burling, J.B. Gilman, C. Warneke, C.E. Stockwell, J. De Gouw, S.K. Akagi, S.P. Urbanski, P. Veres, J.M. Roberts, W.C. Kuster, J. Reardon, D.W.T. Griffith, T.J. Johnson, S. Hosseini, J.W. Miller, D.R. Cocker, H. Jung, D.R. Weise, Coupling field and laboratory measurements to estimate the emission factors of identified and unidentified trace gases for prescribed fires, Atmos. Chem. Phys. (2013) 89-116.

[39] J. Aurell, B.K. Gullett, D. Tabor, Emissions from southeastern U.S. Grasslands and pine savannas: Comparison of aerial and ground field measurements with laboratory burns, Atmos. Environ. 111 (2015) 170-178

[40] E. Garcia-Hurtado, J. Pey, M.J. Baeza, A. Carrara, J. Llovet, X. Querol, A. Alastuey, R. Vallejo, Carbon emissions in Mediterranenan shrubland wildfires: An experimental approach, Atmos. Environ. 69 (2013) 86-93. 